IRA-International Journal of Education \&

Multidisciplinary Studies

ISSN 2455-2526; Vol.10, Issue 01 (January, 2018)

Pg. no. 1-9

Institute of Research Advances

http://research-advances.org/index.php/IJEMS

\title{
Paradise Lost and Paradise Regained as Epics of Political Satire under the Guise of Spiritual Epics: A Critical Inquiry
}

\section{Dr. S. Joseph Arul Jayraj}

Head \& Associate Professor of English, St. Joseph's College (Autonomous), Tiruchirappalli-620 002, Tamil

Nadu, India.

Type of Review: Peer Reviewed.

DOI: http://dx.doi.org/10.21013/jems.v10.n1.p1

How to cite this paper:

Jayraj, S.J.A. (2018). Paradise Lost and Paradise Regained as Epics of Political Satire under the Guise of Spiritual Epics: A Critical Inquiry. IRA International Journal of Education and Multidisciplinary Studies (ISSN 2455-2526), 10(1), 1-9. doi: http://dx.doi.org/10.21013/jems.v10.n1.p1

(C) Institute of Research Advances.

\section{(cc) BY-NC}

This work is licensed under a Creative Commons Attribution-Non Commercial 4.0 International License subject to proper citation to the publication source of the work.

Disclaimer: The scholarly papers as reviewed and published by the Institute of Research Advances (IRA) are the views and opinions of their respective authors and are not the views or opinions of the IRA. The IRA disclaims of any harm or loss caused due to the published content to any party.

Institute of Research Advances is an institutional publisher member of Publishers Inter Linking Association Inc. (PILA-CrossRef), USA. The institute is an institutional signatory to the Budapest Open Access Initiative, Hungary advocating the open access of scientific and scholarly knowledge. The Institute is a registered content provider under Open Access Initiative Protocol for Metadata Harvesting (OAI-PMH).

The journal is indexed \& included in WorldCat Discovery Service (USA), CrossRef Metadata Search (USA), WorldCat (USA), OCLC (USA), Open J-Gate (India), EZB (Germany) Scilit (Switzerland), Airiti (China), Bielefeld Academic Search Engine (BASE) of Bielefeld University, Germany, PKP Index of Simon Fraser University, Canada. 


\begin{abstract}
The paper points out the intention of 'Satire' and inquires into the biographical, historical, sociological, religious, economic, political and literary contexts of John Milton's Paradise Lost (1667) and Paradise Regained (1671). It underscores the poignant example of John Dryden's verse satire, Absalom and Achitophel (1681), which is modelled on John Milton's political epics. It also traces the biographical, historical, sociological, religious, economic, political and literary reasons for the outbreak of the English civil war. Thus, it points out the mutual bond that exists between society and literature, and renders a historical reading of the literary works taken for analysis by exploring the possible purposes with which these texts have been written and the ways in which the meanings of these texts have changed over time owing to multiple interpretations.
\end{abstract}

Keywords: Satire, Biographical approach, Historical approach, Sociological approach, Reader-response.

\title{
Introduction
}

The act of reading and responding to a text can be interpreted as an attempt on the part of a reader to describe what happens in his/her mind. No text can provide the surmised self-contained meaning to any reader because literary texts do not contain any meaning independently in themselves and the readers impregnate the texts with meaning and describe the texts when they try to interpret them. Therefore, the purpose of writing a text does not get fulfilled until it is read and interpreted by readers. But the practical problem that arises in the process of reading and interpreting a text is that no two readers can read and interpret a text exactly alike. Instead of declaring one interpretation as correct and the other as mistaken, an ideal reader will respond to such a problem by taking into consideration the inevitable plurality of readings and meanings.

While taking literary works for inquiry, in order to make the texts reach the readers, the critic, who is also a reader, has to remind himself/herself of the fact that it is indispensable that the texts taken for inquiry are contextualized. Any work of art, "though a period piece, has a global context." Therefore, it is clear that "the context of the text leads the reader to the understanding of the meaning of the text through the same text" (Contemporary Discourse, 263). Only then, a literary inquiry can be carried out systematically, and the impressions of the reader about the worth of literary works will carefully be accounted for. Since literary criticism is a dispassionate judgment on works of literature, the reader should neither intend to pick holes nor to eulogise the artist or the works of literature taken for inquiry. Rather, one is expected to ask and answer rational questions about the literary works taken for scrutiny, methodically try to form and express correct judgment upon the values and merits of works of literature, and earnestly pass on to other readers' intelligent appreciation based on clear understanding of the texts.

In this context, the following question arises in one's mind. What is the role of a reader in shaping what has been written? The question is raised with an intention to explore the relation between the artist and the society-how the profession of authorship has affected what has been written. The question takes into account the "ideology" with which Milton has written works of literature and tries to verify it with the "political ambience" of the time in which these works of literature are written. Harry Levin has stated: “... the relations between literature and society are reciprocal. Literature is not only the effect of social causes; it is also the cause of social effects" (Scott 126). If one scrutinizes the works of literature taken for analysis in the spectrum of light lit by Harry Levin, it will establish the truth that as long as literature maintains its bond with society, the biographical, historical and sociological approaches will enable the readers to delve deep into the life and the literary works of the artist in order to evaluate, interpret and explain the chief functions of the works of art. It is concerned with the sociological aspects of the literary works taken for study by asking question: What cultural, religious, literary, economic, and political values do the texts implicitly or explicitly promote?

At this juncture, the reader is supposed to lay emphasis on the aims, methods and effects the writer creates in the reader through the texts. The reader should take the biography of the writer into consideration and analyze the works of literature to defend them from the point of view of their authors and detractors. The reader must assure that what the person discusses should always be confirmed from the works that are kept under discussion.

\section{The Intention of Milton in Presenting Political Satires under the Guise of Spiritual Epics}

Apart from writing poetry, John Milton also wrote essays and pamphlets, in which he argued against the established views of England. So, he faced many threats. Nevertheless, he continued to champion the cause of absolute freedom of the individual because he believed that power is exercised with authority. When too much 
power is invested with an individual ruler, the chance of the ruler becoming a dictator is more. In such a situation, all decisions are normally made by one authority.

Milton did not trust anyone who could claim power over anyone else, and believed that leaders should be fit to rule their subjects. He believed in a strict social and political hierarchy in which people would obey their leaders, and leaders serve their people. But despite his belief, the social hierarchy that actually existed in his day was extremely corrupt, and he directly challenged it throughout his life. Milton was of the staunch opinion that Charles was not fit to rule his subjects because he did not possess superior faculties or virtues.

Even at the early age, Milton read the classical epics namely Homer's Odyssey and Iliad and Virgil's Aeneid and these epics created indelible impressions in the mind of young Milton. He fantasized about bringing such artistic excellence to the English language and aspired to write epic poems in English. Milton considered many topics for his epics and finally chose to write his epics on a distinctly British topic that would inspire nationalist pride in his countrymen. Finally, Milton chose the story of Adam and Eve for his epics. Having chosen the theme, he knew very well that the content of the epics is known to the people and no one would be interested in reading it.

Satire is a style of writing that intends to ridicule and expose the foibles of individual characters and follies of the society with an intention to initiate change. The flaws that are satirized by Milton can be seen in the biographical, historical, sociological, religious, economic, political and literary contexts of England. He played a trick of carefully amalgamating the political upheaval of his time with that of the biblical story and presented political satires under the guise of spiritual epics. Thus, Milton combined his political and theological beliefs and gave a vent to them in the form of epic poems. The rest of the paper attempts to analyze his exuberance of craftsmanship and tries to justify its stance with the proofs culled out from the texts taken for analysis.

\section{The Biographical Approach to Select Works of Milton}

Biographical approach begins with an insight that literature is written by an author, and by understanding an author's life, the reader can thoroughly comprehend the work of literature. In other words, a reader bases his/her interpretation on what is in the text and relies on the biographical data of the author to amplify the meaning of the text. For example, the reader must be aware that Milton married thrice (Mary Powell 1642-1652, Katherine Woodcock 1656-1658 and Elizabeth Mynshull 1662-1674). Milton was deserted by his wife, Mary Powell. It is this incident which provoked him to write four prose tracts namely "The Doctrine and Discipline of Divorce: Restor'd to the Good of Both Sexes, From the Bondage of Canon Law" (1643-1644), "The Judgment of Martin Bucer Concerning Divorce" (1644), "Colasterion" (1645) and "Tetrachordon" (1645) (https://www.britannica.com/ biography/John-Milton/Divorce-tracts). In "Colasterion" and "Tetrachordon," Milton presents a vigorous, cogent and radical argument in favour of sanctioning divorce to the partners based on the concept that the wedlock, which yokes two individuals without taking into account the incompatibility of the partners and without mutual love and fidelity, is detrimental against one's personal liberty. Under such circumstances, irrespective of the fact that marriage is a holy matrimonial bond, it loses its sanctity. Thus, both treatises undertake to defend Milton's "The Doctrine and Discipline of Divorce: Restor'd to the Good of Both Sexes, From the Bondage of Canon Law." In order to make his arguments irrefutable, Milton bases his arguments on "The Judgment of Martin Bucer Concerning Divorce" (1644) and marshals it with biblical passages as proof and obtains a prepublication license from the Parliament. He argues in his pamphlet that Christ does not abrogate the permission for divorce mentioned in Deuteronomy 24:1, because He clarifies the doubts of the Pharisees on this issue in Matthew 19.

On 23 November 1644, Milton addressed the English Parliament and argued vehemently against Parliament's 1643 Ordinance for the Regulating of Printing, which required authors to have a license approved by the government before their works could be published (https://www.britannica.com/topic/Areopagitica). These arguments in opposition to the censorship of speech and writing were distributed via pamphlet on the title "Areopagitica."

\section{The Historical Approach to Paradise Lost and Paradise Regained}

Historical approach enables the reader to understand a literary work by investigating the social, cultural and intellectual contexts that produced it - a context that necessarily includes the biography and milieu of the writer. "Art is not created in a vacuum," critic Wilbur Scott observed, "it is the work not simply of a person, but of an 
author fixed in time and space, answering a community of which he is important," because of the articulate part he plays (Scott 123). Historical approach is less concerned with explaining a work's literary significance for today's readers than with helping them understand the work by recreating, as nearly as possible, the exact meaning and the impact it has created on its readers. A historical reading of literary works begins by exploring the possible purpose with which these texts have been written, and ends by explaining the ways in which the meanings of these texts have changed over time.

\section{The Sociological Approach to Paradise Lost and Paradise Regained}

Sociological approach empowers the reader to examine a work of literature in the cultural, religious, economic and political contexts in which it is written. This approach aids the reader to explore the relationship between the artist and the society. Sometimes, it assists the reader in considering the sociological status of the author to evaluate how the profession of the writer in a particular milieu has affected what is written. Sociological approach also enables the reader to analyze the social content of literary works - cultural, literary, religious, economic and political values which a particular text either implicitly or explicitly promotes. Thus, sociological approach enlightens the reader's understanding of the text and enables him/her to fulfill the purpose of the craftsmanship of the author.

Sociological approach is employed here to scrutinize the social, religious, literary, economic and political elements of Milton's Paradise Lost and Paradise Regained. Milton's works of art do not ignore political issues. They do make political statements because these works of art are written with the intentions that England should attain ideal social, literary, religious, economic and political status. Thus, the historical and the sociological perspectives of the texts taken for study are used as analytical tools, which do not fail to illuminate the readers' understanding of the texts.

A sociological view of Milton's Paradise Lost throws more light on the political uncertainties that prevailed during the English Civil War. It also helps one study the political ideas expressed in Paradise Lost or discuss how these concepts help Milton determine the subject(s) taken for discussion. In this context, it is essential to summarize the biography of John Milton (1608-74), an English poet, prose writer, polemicist and civil servant for the Commonwealth of England, who was writing at the time of cultural, literary, religious, economic, and political flux in England.

As a strong supporter of freedom, he supported the Parliamentarians during the civil war, which began in 1642. In his political writing, Milton addressed particular themes at different periods. In his 1641 treatise, "Of Reformation," Milton expressed his dislike for Catholicism and episcopacy, presenting Rome as a modern Babylon, and bishops as Egyptian taskmasters. These analogies conform to Milton's puritanical preference to the Old Testament imagery. Through the Interregnum, he rescued England from the trappings of a worldly monarchy, as an elect nation akin to the Old Testament Israel, and shows its leader, Oliver Cromwell, as a latter-day Moses (www.poemhunter.com/john-milton/biography).

\section{Religious Background of the English Civil War}

The Catholic Church has been endorsing the line of emperors based on the Biblical justification of submission to the monarchy, which can be traced from the following references in the Bible:

1. Saul is the first human king of Israel chosen by God. "When Samuel saw Saul, the LoRD told him, "Here is the man of whom I spoke to you! He it is who shall rule over my people" (1 Samuel 9:17).

2. In the New Testament, St. Peter commands all Christians,

Be subject for the Lord's sake to every human institution, whether it be to the emperor as supreme, or to governors as sent by him to punish those who do wrong and to praise those who do right. ... Honour all men. Love the brotherhood. Fear God. Honour the emperor. (1 Peter 2:13-14, 17)

3. St. Paul reiterates St. Peter's claim that subjects should be obedient to the rulers because they are appointed by God.

Let every person be subject to the governing authorities. For there is no authority except from God, and those that exist have been instituted by God. Therefore he who resists the authorities resists what God has appointed, and those who resist will incur judgment. For rulers are not a terror to good conduct, but to bad. Would you have no fear of him who is in authority? Then do what is good, and you will receive his approval, for he is God's servant for your good. But if you 
do wrong, be afraid, for he does not bear the sword in vain; he is the servant of God to execute wrath on the wrong doer. Therefore one must be subject, not only to avoid God's wrath but also for the sake of conscience. For the same reason you also pay taxes, for the authorities are ministers of God, attending to this very thing. Pay all of them their dues, taxes to whom taxes are due, revenue to whom revenue is due, respect to whom respect is due, honour to whom honour is due. (Epistle to the Romans 13:1-7)

4. They said, "Caesar's." Then he said to them, "Render therefore to Caesar the things that are Caesar's..." (Matthew 22: 21).

5. Jesus answered him, "You would have no power over me unless it had been given you from above; ..." (John 19: 11).

a. "Divine right of kings, political doctrine in defense of monarchical absolutism, which asserted that kings derived their authority from God and could not therefore be held accountable for their actions by any earthly authority such as a parliament" (https://www.britannica.com/topic/divine-right-of-kings).

b. When King James I addressed the Parliament in1610, his Divine Right Theory was based on the following concepts of the Bible:

. . The state of monarchy is the supremest thing upon earth, for kings are not only God's lieutenants upon earth and sit upon God's throne, but even by God himself they are called gods. There be three principal [comparisons] that illustrate the state of monarchy: one is taken out of the word of God, and the two other out of the grounds of policy and philosophy. In the Scriptures kings are called gods, and so their power after a certain relation compared to the Divine power. Kings are also compared to fathers of families; for a king is truly parens patriae [parent of the country], the politic father of his people. And lastly, kings are compared to the head of this microcosm of the body of man ... (Prothero 293-294; 400-401)

c. In spite of these all significant and pervasive references in the Bible and other political sources, Regicide was practised in the history of England for political reasons. For example,

Before the Tudor period, English kings had been murdered while imprisoned (for example, Edward II or Edward V) or killed in battle by their subjects (for example Richard III), but none of these deaths is usually referred to as regicide. The word 'regicide' seems to have come into popular use among foreign Catholics when Pope Sixtus V renewed the Papal bull of excommunication against the "crowned regicide" Queen Elizabeth I, for-among other thingsexecuting Mary, Queen of Scots, in 1587. Elizabeth had originally been excommunicated by Pope Pius V, in Regnans in Excelsis, for converting England to Protestantism after the reign of Mary I of England. The defeat of the Spanish Armada and the "Protestant Wind" convinced most English people that God approved of Elizabeth's action. (http://encyclopedia2.thefreedictionary.com/ regicide)

Therefore, based on these concepts of supremacy, Charles I believed in his divine right to rule.

Brought up from infancy to believe that kings ruled by Divine Right, he thought that it beneath his dignity to take his people, or their representatives, into his confidence (A History of Britain, 444) ... It was, however, by his religious policy that Charles and Laud most inflamed the temper of the opposition. Charles I was opposed to the Puritans by religious conviction, being what is called a 'High Churchman'. ...; he stopped, for example, the custom of suing St. Paul's cathedral as a meeting place for gossip and merchants. (A History of Britain, 451)

But the Parliamentarians felt that they represented the people and so wanted to assert their say in the ruling of the country. The Army of the Parliamentarians was dominated by Puritans and they insisted on having one faith and one religion in England. So in 1646, the Parliament passed bills to suppress all the religious sects in England. Commenting on it, John Milton wrote, "A little generous prudence, a little forbearance of one another, and some grain of charity, might win all ... into one brotherly search after truth" (A History of Britain, 469). This element of intolerance and religious fanaticism paved the way for the fall of the Puritans. Had they practised these wise words, it would have been well not only to the People of England in general but also to John Milton himself in particular.

\section{Economic Background of the English Civil War}

The English Crown derived an income from:

(i) Rents on Crown lands and old feudal dues, (ii) the ancient customs, (iii) tonnage and poundage, and this was often supplemented by: (iv) special taxes called subsidies, which 
could only be levied by consent of Parliament, (v) additional duties on imports, known as impositions, (vi) the sale of monopolies and patents, and (vii) the collection of what were fictitiously called 'benevolences' (A History of Britain, 440). ... The tax which aroused most wrath was the levying of Ship-Money. ... The real grievance was that Ship-Money had been levied without consent of Parliament, and was therefore contrary to the Petition of Right (A History of Britain, 451).

(ii)

\section{Political Background of the English Civil War}

On 13 April 1640, King Charles I summoned the Short Parliament, which brought his eleven-year personal rule to an end and also led to the outbreak of the English Civil War in 1642. It was fought between the forces of King Charles I and the forces of Parliament (A History of Britain, 454-455, 457). The Royalists were led by Charles I, whereas the Parliamentarian forces, otherwise known as the Roundheads, were led by Oliver Cromwell. The Puritan army defeated the Royalists, and Charles I was decapitated on a charge of high treason in 1649 (A History of Britain, 472). Oliver Cromwell became Lord Protector. He dismissed the Parliament and became a despot of sorts. Politically, Oliver Cromwell believed that the Parliament should have more power than the king, and favoured Constitutional Monarchy from 1649 to 1660. When he died, his son, Richard Cromwell, took over but didn't last long. Charles II, brother of Charles I, ascended to the throne in 1660. Thus, the political history of England is replete with examples of regicide, and the root cause of this evil germinates out of the principle of politicizing spirituality instead of spiritualizing politics.

\section{Literary Background of the English Civil War}

The evidences of regicide being practised in the Western literatures were plentiful before the English Civil War broke out. The ennobling quality of being hospitable to the guests and the hosts requires a minimum etiquette of respecting each other at least during a brief stint of their visit. Breach of confidence of any kind against this principle of hospitality is considered to be the worst form of crime because this unimaginable treachery violates all the laws of natural justice and the milk of human kindness. Not only are the histories of the world, but also the literatures of the world replete with examples of this heinous act as follows:

(i) In Homer's Odyssey, Odysseus and his men land up in an island of savage brutes. They enter into a cave of a one-eyed giant named Polyphemos, in his absence. When the absentee host-Polyphemos - returns and finds intruders in his cave, he makes the uninvited guests his prisoners and feeds on them, which is one of the many nasty things that hosts can do to their guests. Odysseus and his Greek companions get the giant so drunk that he falls into a stupor-whereupon they drive a burning stake into his eye. The next day, when the giant rolls back the boulder to let his flock of sheep out of the cave, the Greeks sneak out by clinging to the underbellies of the sheep and then sail away.

(ii) Inferno, the first part of Dante's epic Divine Comedy, tells a story of treacherous hosts and guests who are stuck in the deepest circle of hell for their sins of retaliation. A Guelph lord named Alberigo's political power is threatened by Manfred. Struck by Manfred in the midst of a dispute, Alberigo pretends to forgive the blow as an act of youthful impetuosity and then invites Manfred and one of his sons to a banquet. When the host says, "Bring the fruit," armed men rush from behind a curtain and butcher the guests. As a result, Alberigo is stuck forever in ice right in front of another treacherous host, Branca d'Oria, who kills his father-in-law after serving him dinner.

(iii) In the Old English epic of Beowulf, King Hrothgar, the ruler of the Danes, is troubled by the rampages of a demon named Grendel. Though King Hrothgar himself is a great warrior, he is unable to protect his people. In the meantime, a young warrior named Beowulf comes to the rescue of the Danes because Hrothgar helped out his father. Beowulf wrestles against the demon, Grendel, and kills him and his demonic mother.

(iv) In Richard II, King Richard kills Henry Bolingbroke's uncle, the Duke of Gloucester. John of Gaunt (Duke of Lancaster, uncle to the king and Bolingbroke's father) dies after accusing Richard of improper government. Richard orders the seizure of Gaunt's property and denies Bolingbroke his inheritance. Bolingbroke is sent in exile. While Richard is in Ireland, Bolingbroke returns to England with an army and persuades his uncle York that he has come for his rightful inheritance and not for rebelling against the crown. Richard returns from Ireland and discovers that his Welsh troops have deserted him and York has allied himself with Bolingbroke. Bolingbroke meets the King with his supporters and promises him to surrender his arms, if the banishment is repealed and his inheritance is restored. Richard agrees to his demand. Richard's cousin, the Duke of Aumerle, is accused of murdering the Duke of Gloucester. Bolingbroke arrests everyone involved in the crime. Richard agrees to abdicate and Bolingbroke announces his coronation. York discovers that his son Aumerle hatches a plot to restore 
Richard. Aumerle confesses to Bolingbroke and is pardoned and the deposed King Richard II is beheaded.

(v) In Macbeth, Scottish King Duncan is murdered by his Commander Macbeth, who is at once his subject and his host, when the King spends a night at the castle of Macbeth. A few days later, after becoming king himself, Macbeth hosts a banquet for various Scottish lords including Banquo. But since Macbeth has been told that Banquo's heirs will inherit the throne, he murders Banquo on the day of the feast. Banquo's sons escape from the attack and later avenge the death of their father.

To Milton as well as to any reader, the point of moral that is obvious in these stories of literature is that hosts and guests mistreat each other in the form of the benign reciprocity of hospitable payback - the guest later becomes the host—gives way to malign reciprocity, where payback culminates in retaliation.

\section{Milton's Stance in the English Civil War as Embedded in his Works of Literature}

Milton continued to write between 1649 and 1654 in support of the execution of Charles I, and in polemic justification of the regicide and the Parliamentarian regime that followed. He translated the documents of the government into Latin and wrote materials in support of the Commonwealth (the republican government that ruled from 1649 to 1660). These historical contexts explain the point beyond any fear of doubt that Milton wrote Paradise Lost (1667) after the rule of Oliver Cromwell. He grieved over the fall of the Commonwealth which prompted him to write an epic poem keeping Oliver Cromwell as its hero. But he was terribly scared of writing such an epic in favour of the lost hero, Oliver Cromwell, and that too during the regime of Charles II, the brother of the beheaded King Charles I. Though Milton did not like to have King Charles I as the hero of Paradise Lost (1667) which he modelled on the biblical story, he had no other choice; that was the hitch that he had in the plot of his epic. As a staunch supporter of Parliamentarians, he was personally willing to promote Oliver Cromwell as the hero of his epic, but the biblical tradition and the frame work of the plot of the epic tradition did not allow him to violate the rules and tradition. Yet he did violate both very subtly by portraying Satan, an anti-hero, as an omnipresent and omnipotent hero of the epic though formally he declared the objective of the plot. Though the poet was compelled to take side with God's cause in the opening stanza of Paradise Lost, Book I (1667) wherein he argues, "I may assert eternal providence,/And justify the ways of God to men" (Line 26), he did it against his will in favour of falling in line with the epic tradition. The poet apparently portrayed God as one who was arbitrary in setting the law, and he deliberately depicted Satan reasonable for having violated the law. Milton was able to delineate the character of Satan as the hero of the epic with an ulterior motive very subtly and without the cognizance of the reader. Though the poet intended to have control over the character of Satan, it was the poet who came under the control of the character of Satan. In the process of the crafting of Paradise Lost, Milton pretends to indulge in condemning and debunking the character of Satan. But he skillfully fulfills his hidden agenda of crafting and promoting the anti-hero as the hero of his epic poem. In Paradise Lost, Milton drew Hebrew and English history together into a pattern with great ingenuity and wit and enriched his allegory with a wealth of allusion to the Bible to reveal a hidden meaning, which was typically a political one.

After a gap of fourteen years, by following the foot-prints of John Milton, John Dryden wrote a similar satire in verse namely Absalom and Achitophel in 1681, and based his work on a biblical incident that is narrated in the Old Testament, 2 Samuel 13-19.

The whole issue of Absalom and Achitophel was about the Exclusion crisis, a contemporary episode in which anti-Catholics, notably the earl of Shaftesbury, sought to bar James, duke of York, a Roman Catholic convert and brother to King Charles II, from the line of succession in favour of the king's illegitimate (but Protestant) son, the duke of Monmouth. Dryden turned his wit on the Whigs, a political party that tried to break the traditional line of succession and prevented James, Duke of York, from ascending to the throne. He devoted half of the poem to scathing portraits of Whig leaders, whose real names he hid using Biblical names like Absalom and Achitophel and another section to favourable portraits of James' faithful supporters. (https://www.britannica.com/topic/Absalom-and-Achitophel)

Milton praised Oliver Cromwell as the Protectorate was set up. However, he had major reservations later. When Cromwell seemed to be backsliding as a revolutionary, after a couple of years being in power, Milton moved closer to a group of disaffected republicans who stood for the fulfillment of his most optimistic ideas of free speech. Milton foresaw the Restoration in 1659-60 and wrote to head it off. Because of his commitment to republicanism, Milton could not be called an early apostle of liberalism. The reason is as follows: As Richard 
Cromwell fell from power, Milton, a vociferous advocate on behalf of the regicide, became silent on political matters as Charles II ascended to the throne.

The Restoration of the Stuart monarchy in 1660 began a new phase in Milton's work. Milton's the blankverse epic poem Paradise Lost, was composed by the blind and impoverished Milton and was published in 1667. Milton lost his physical eyesight in 1652 and he did lose his political vision also due to the crumbling political ambience in England, which he expressed through Paradise Lost (1667). Milton encodes many references to his unyielding support for the "Good Old Cause." In Paradise Lost (1667), Milton mourns the end of the godly Commonwealth. The Garden of Eden allegorically reflects Milton's view of England's recent fall from Grace. In Samson Agonistes (1671), Samson's blindness - akin to Milton's own lost sight—is a metaphor for England's blind acceptance of Charles II as king. Paradise Lost (1667) deals with the rebellion of Lucifer, the Arch-angel, and his companions (Oliver Cromwell and his supporters) against God (Charles I, the King of England) and their expulsion (the expulsion of Oliver Cromwell and his supporters) from Heaven (from England). Thus, these texts are loaded with his personal despair at the failure of the Revolution. Paradise Regained (1671) celebrates the spiritual redemption of humankind through Jesus Christ, and through this epic Milton subtly implies the political restoration of Charles II to the English throne ("Life in England under Oliver Cromwell," http://www.historylearningsite.co.uk/ stuart-england/life-in-england-under-oliver-cromwell/).

\section{Critiques on Paradise Lost}

a. William Blake and P. B. Shelley have believed Satan to be the hero of Paradise Lost (1667). William Blake has found Milton's depiction of God so far inferior to his depiction of Satan that he considered Milton to be an unwitting Satanist (https://www.dartmouth.edu/ milton/ readingroom/pl/intro/text.shtml).

b. As Joseph Addison observes, the plot of Paradise Lost starts with the conspiracy in hell, proceeds with its execution of the conspiracy on earth, and its punishment by heaven (Bond 62-64). Milton either consciously or unconsciously does ignite a feeling in the reader that the epic implies the future of the whole mankind, England as a nation, and Milton's hopes, in particular, are under the grip of misfortune and in utter despair.

c. P. B. Shelley writes, "Milton's Devil as a moral being is as far superior to his God, ... Milton has so far violated the popular creed (if this shall be judged to be a violation) as to have alleged no superiority to his God over his Devil" (https://www.saylor.org/site/wp-content/uploads/2011/01/A-Defense-of-Poetry.pdf, p.27).

d. Having understood the hidden agenda of Milton accurately, C. S. Lewis, in his Preface to Paradise Lost (1942), has written:

Every poem can be considered in two ways - as what the poet has to say, and as a thing which he makes. From the one point of view it is an expression of opinions and emotions; from the other, it is an organization of words which exists to produce a particular kind of patterned experience in the readers (Preface to Paradise Lost, 2).

e. Barbara Kiefer Lewalski comments:

Unlike classics such as the Iliad and the Aeneid, Paradise Lost has no easily identified hero. The most Achilles-like character in the poem is Satan, whom Milton surrounds with epic matter and motivations, epic genre conventions, and constant allusions to specific passages in famous heroic poems (Paradise Lost and the Rhetoric of Literary Forms, 55).

f. Though the problems inherent in viewing Satan as a hero of Paradise Lost have led Barbara Lewalski to reject this idea "by measuring Satan against the heroic standards, we become conscious of the inadequacy and fragility of all the heroic virtues celebrated in literature, of the susceptibility of them all to demonic perversion" (Paradise Lost and the Rhetoric of Literary Forms, 78).

g. Another possibility for the hero of the epic is the Son of God, but although he is an important force in the poem, the story does not ultimately spine around him (https://www.dartmouth.edu/ milton/reading_room/pl/intro/ text.shtml).

Despite the Restoration of the monarchy, Milton did not lose his personal faith in religion and politics. Samson Agonistes (1671) shows how the loss of national salvation did not necessarily preclude the salvation of the individual, while Paradise Regained (1671) expresses his continuing belief in the promise of Christian salvation through Jesus Christ. Though he maintained his personal faith in Christ, in spite of the defeats suffered by his cause, he was alienated from the Church of England by Archbishop William Laud, and then moved away similarly from the Dissenters by their denunciation of religious tolerance in England (www.religionfacts.com/john-milton). 


\section{Conclusion}

The arguments that are placed before the reader through this paper are not based on mere surmises but are deeply rooted in biographical, historical, sociological, religious, economic, political and literary contexts which are strongly supported with apt evidences drawn from Paradise Lost and Paradise Regained of Milton, which are taken for scrutiny. Thus, it is made crystal clear that the epics, Paradise Lost and Paradise Regained, are written as political satires on the Tudor period under the guise of spiritual epics, which are based on biblical story of the fall of man and his redemption.

\section{References}

[1] Bond, Donald. F. Critical Essays from the Spectator. Oxford: Clarendon Press. 1970. Print.

[2] Carter, E. H., \& Mears, R. A. A History of Britain. New Delhi: Surjeeth Publications, 1960. Print.

[3] Danielson, Dennis. Ed. Barbara Kiefer Lewalski. Ch. 8. "The genres of Paradise Lost." The Cambridge Companion to Milton. Cambridge: CUP, 1997. Accessed 28 May 2017. https://www.cambridge.org/core/books/the-cambridgecompanion-to-milton/the-genres-of-paradiselost/ C3BBF346DB263F6AC2F143741FF8CFA5, pp. 113-129. Accessed 29 Sep. 2017.

[4] Encyclopedia Britannica Inc. 2 Sep. 2007. Absalom and Achitophel. https://www.britannica.com/topic/Absalom-andAchitophel Accessed 22 June 2017.

[5] Encyclopedia Britannica Inc. 2017. https://www.britannica.com/topic/divine-right-of-kings Accessed 22 June 2017.

[6] ---. 2017. The Doctrine and Discipline of Divorce. https://www.britannica.com/biography/John-Milton/Divorce-tracts Accessed 15 July 2017.

[7] ---. 2017. "Areopagitica: A Speech of Mr John Milton for the Liberty of Unlicenc'd Printing, to the Parliament of England." https://www.britannica.com/topic/Areopagitica Accessed 12 July 2017.

[8] FARLEX. The Free Dictionary. https://www.thefreedictionary.com/regicide. Accessed 15 July 2017.

[9] Jayraj, Joseph Arul. S. Jan. 2012. "The Context is Indispensable in the Understanding of the Text: A Study in the Light of New Criticism." Nikam Madhavi ans Sudhir Nikam. Ed. Contemporary Discourse, Volume 3, Issue 1, January 2012, 260-264, Print.

[10] “John Milton.” ReligionFacts.com. 22 Nov. 2016. www.religionfacts.com/john-milton Accessed 8 Dec. 2017.

[11] Lewalski, Barbara Kiefer. Paradise Lost and the Rhetoric of Literary Forms. Princeton: Princeton University Press, 1985. http://muse.hju.edu/book/33554 Accessed 29 Nov. 2017.

[12] Lewis, C. S. A Preface to Paradise Lost. Oxford: OUP, 1969. http://portalconservador.com/livros/C-S-Lewis-APreface-to-Paradise-Lost.pdf Accessed 18 Oct. 2017.

[13] PoemHunter.Com "Biography of John Milton." 6 Jan. 2017. http://www.poemhunter.com/john-milton/biography Accessed 18 Oct. 2017.

[14] Scott, W. Five Approaches of Literary Criticism. New York: Macmillan, 1962. Print.

[15] Shelley, P. B. Defence of Poetry and Other Essays. English Essays: Sidney to Macaulay. The Harvard Classics. 190914. https://www.saylor.org/site/wp-content/uploads/2011/01/A-Defense-of-Poetry.pdf Accessed 2 Nov. 2017.

[16] The Holy Bible (Revised Standard Version). Bangalore, Karnataka: Collins, 1980. Print.

[17] Then Again. 2005-2016. Select Statutes and Other Constitutional Documents Illustrative of the Reigns of Elizabeth and James I, 3 Edn. G. W. Prothero. Ed. Oxford: Clarendon Press, 1906, 400-401 \& 293-294. Print. http://www.thenagain.info/Classes/Sources/JamesI.html Accessed 13 Dec. 2017.

[18] Trueman, C. N. 17 Mar. 2015. 16 Aug. 2016. "Life in England under Oliver Cromwell." The History Learning Site. http://www.historylearningsite.co.uk/stuart-england/life-in-england-under-oliver-cromwell/. Accessed 18 Dec. 2017.

[19]Zukerman, Cordelia \& Thomas H. Luxon. 1997. "Answerable Style": The Genre of Paradise Lost. https://www.dartmouth.edu/ milton/reading_room/pl/intro/text.shtml\#genre Accessed 17 Dec. 2017. 